\title{
Phage X: A Plasmid-dependent, Broad Host Range, Filamentous Bacterial Virus
}

\author{
By D. E. BRADLEY, ${ }^{1}$ J. N. COETZEE, ${ }^{2 *}$ TINA BOTHMA ${ }^{2}$ \\ AND R. W HEDGES ${ }^{3}$ \\ ${ }^{1}$ Faculty of Medicine, Memorial University of Newfoundland, St John's, Newfoundland, \\ Canada A1B 3 V6 \\ ${ }^{2}$ Department of Microbiology, University of Pretoria and Bacterial Genetics Research Unit \\ of the South African Medical Research Council, P.O. Box 2034, Pretoria 0001, South Africa \\ ${ }^{3}$ Department of Bacteriology, Royal Postgraduate Medical School, Hammersmith Hospital, \\ London W12 OHS, U.K.
}

(Received 26 February 1981)

\begin{abstract}
Phage X was isolated from sewage as plating on Escherichia coli or Salmonella typhimurium strains harbouring the incompatibility group X plasmid R6K. It also plated on a strain of Serratia marcescens carrying this plasmid. It failed to form plaques on Proteus mirabilis, P. morganii or Providencia alcalifaciens harbouring R6K, but did multiply on them. No phage increase occurred with homologous $\mathrm{R}^{-}$strains. Phage $\mathrm{X}$ also plated or registered an increase in titre on $E$. coli or $S$. typhimurium strains carrying various plasmids of incompatibility groups $\mathrm{M}, \mathrm{N}, \mathrm{P}-1, \mathrm{U}$ or $\mathrm{W}$ as well as the unassigned plasmid R775. It adsorbed to pili determined by a group P-10 plasmid in a Pseudomonas aeruginosa strain but did not multiply on this organism. The phage was filamentous and curly, resistant to ribonuclease and diethyl ether and sensitive to chloroform. It adsorbed to the tips of pili.
\end{abstract}

\section{INTRODUCTION}

The $\mathrm{X}$ incompatibility group was established (see Hedges et al., 1973) with the plasmid R6K (Kontomichalou et al., 1970) as prototype. Subsequently, R485 (Hedges et al., 1973) and then R778b, R779, R711b and R712b were included (Hedges, 1974). However, later work on the incompatibility reactions of the plasmids, together with the morphologies and phage adsorption specificities of their pili, revealed inconsistencies which led to the removal of R711b and R778b from the group (see Bradley, 1977, 1978 b). The latter plasmids initiated a new incompatibility group, D (Datta, 1979). The position of R485 has also been in doubt: while incompatible with R6K, it determined thin pili, not typical X pili (Bradley, 1978a). However, Bradley (unpublished) has detected X pili as well, so that R485 is now believed to truly belong to group $\mathrm{X}$. Other group $\mathrm{X}$ plasmids have subsequently been identified in bacteria belonging to various genera of the family Enterobacteriaceae from different continents (Caudry \& Stanisich, 1979; McConnell et al., 1979; Richards \& Nugent, 1979; see Bradley, $1980 \mathrm{~b}$ ).

The pili coded for by IncX plasmids are thick and flexible, and, together with those determined by plasmids of incompatibility groups C, D, the F complex, H1, H2, J, T, V, Com 9 and the single plasmid $F_{o} l a c$, constitute pilus morphological group 2 of Bradley $(1980 a)$. X pili are serologically unrelated to the pili of any other incompatibility group of plasmids (Bradley, $1980 \mathrm{~b}$ ).

In this paper we describe the properties of a bacteriophage which was isolated on bacteria harbouring R6K and which adsorbed to the tips of $\mathrm{X}$ and other conjugative pili. 


\section{METHODS}

Bacteria and plasmids. Bacteria used were Proteus mirabilis strain PM5006, Proteus morganii strain 2815nal-r, Salmonella typhimurium strain LT2trpA8, Providence alcalifaciens strain P29nal-r, Escherichia coli strains J53, J53-1 and J62-1 (Coetzee et al., 1979) and JE2571 (Bradley, 1980 b) and Serratia marcescens strain SM89 (Sirgel et al., 1981). Pseudomonas aeruginosa PU21 strains carrying representative plasmids of incompatibility groups P-2, P-3, P-5, P-7, P-8, P-9, P-10 or P-11, were supplied by G. A. Jacoby, Ps. aeruginosa PAO1150.1(R91.5) being constructed from one of these. Other plasmids were from the collection of Naomi Datta (Datta, 1977) and were transferred to appropriate organisms. Plasmid-carrying strains are listed in Table 1.

Bacteriophages. The RNA-containing bacteriophage C-1 (Sirgel et al., 1981) was used as a positive control in ribonuclease sensitivity tests and phage IKe (Khatoon et al., 1972) was used in immune electron microscopy.

Media, antibiotics, transfer of plasmids by conjugation, general phage techniques, production of phage lysates and organic solvent sensitivity tests for phages. The materials and methods used were as described and referred to by Coetzee et al. (1979). Organisms were incubated at $37^{\circ} \mathrm{C}$ apart from those harbouring $\mathrm{T}$ group plasmids when incubation was at $25^{\circ} \mathrm{C}$.

Isolation of a bacteriophage specific for bacteria harbouring plasmid R6K. Attempts were made to enrich the possible specific phage content (see Meynell \& Lawn, 1968) of $5 \mathrm{ml}$ of sewage from the main Pretoria sewage works by addition of an equal volume of an exponentially growing culture of strain J53(R6K) or LT2 $\operatorname{trp} A 8(\mathrm{R} 6 \mathrm{~K})$. After incubation for $1 \mathrm{~h}$ the mixtures were diluted with equal volumes of warm broth and incubated overnight. The cultures were then filtered separately through $0.45 \mu \mathrm{m}$ pore-size Millipore membranes and drops of the filtrates were spotted on soft agar lawns of J53(R6K), LT2trpA $8(\mathrm{R} 6 \mathrm{~K})$ and both background strains.

Concentration of bacteriophage. Phage lysates were concentrated using polyethylene glycol (mol. wt 6000) and $\mathrm{NaCl}$ at final concentrations of $6 \%(\mathrm{w} / \mathrm{v})$ and $0.5 \mathrm{M}$, respectively (Yamamoto et al., 1970). Pellets were resuspended in small volumes of distilled water.

Ribonuclease sensitivity. Drops of phage $\mathrm{X}$ suspension $\left(1 \times 10^{8}\right.$ plaque-forming units $\left.\mathrm{ml}^{-1}\right)$ were spotted on plates containing strain $\mathrm{J} 53(\mathrm{R} 6 \mathrm{~K})$ with pancreatic RNAase $(\mathrm{BDH})$ at a final concentration of $25 \mu \mathrm{g} \mathrm{m} \mathrm{l}^{-1}$ in top-layer agar (Watanabe \& August, 1967). Similar plates, seeded with LT2trpA\&(P-lac), were spotted with phage C-1.

Bacteriophage increase. An exponentially growing culture of the donor plasmid-bearing organism $(0.1 \mathrm{ml})$ under test was mixed with an equal volume of stationary phase recipient (strain J53) on a Millipore membrane resting on nutrient agar. After overnight incubation, the growth was gently washed off by suspending the membrane in $5 \mathrm{ml}$ warm broth. To $1 \mathrm{ml}$ of this broth suspension, possibly containing transconjugants temporarily derepressed for pilus synthesis (Bradley, $1980 \mathrm{a}), 0.1 \mathrm{ml}$ of a suspension of phage $\mathrm{X}\left(1 \times 10^{10}\right.$ plaque-forming units $\mathrm{ml}^{-1}$ ) and $4 \mathrm{ml}$ soft top-layer were added and the mixture was poured over the surface of a nutrient agar plate and allowed to set. After overnight incubation, the phage was harvested and the titre on strain J53(R6K) was determined (Sirgel et al., 1981). Cultures of J53(R6K) and J53 were used as donors in similar experiments for positive and negative controls, respectively. A phage titre at least 10-fold higher than the negative control in each of three independent experiments was taken as a positive result.

Preparation of pili and electron microscopy. The bald host strains JE2571 or PAO1150.1 carrying an appropriate plasmid were grown overnight $(6 \mathrm{~h}$ for $\mathrm{X}$ pili) on selective plates. The growth was then scraped off and a pilus suspension was prepared by grinding the bacteria in a Thomas Teflon Tissue Grinder with $0.9 \%(w / v)$ $\mathrm{NaCl}$ solution (Bradley, 1977). After the removal of bacteria by centrifugation, the suspensions were used to test for the adsorption of phage $\mathrm{X}$ to pili by mixing them with equal volumes of phage suspension in broth followed by incubation at $37^{\circ} \mathrm{C}$ for $15 \mathrm{~min}$. Carbon-coated electron microscope specimen support grids were then touched on to the surfaces of the various mixtures, followed by negative-staining with $1 \%(\mathrm{w} / \mathrm{v})$ sodium phosphotungstate solution. The same mounting process was used for phage $\mathrm{X}$ suspensions without the addition of pili.

For immune electron microscopy, grid-labelling with antiserum to bacteriophage IKe (anti-IKe kindly supplied by R. B. Grant) was done by the method of Lawn (1967).

The electron microscope was calibrated for phage $\mathrm{X}$ measurement with the catalase crystal lattice.

\section{RESULTS}

The objective was to obtain an R6K-specific bacteriophage and, at first attempt, a phage was isolated which plated on both $E$. coli J53(R6K) and $S$. typhimurium LT2trpA8(R6K). The phage did not plate on homologous $\mathrm{R}^{-}$strains. It was named phage $\mathrm{X}$ and was routinely propagated on strain J53(R6K).

\section{Properties of phage $X$}

Plaque morphology. The phage formed relatively clear plaques on susceptible organisms. They were uniform, about $1.0 \mathrm{~mm}$ in diameter, and did not vary on different hosts. 

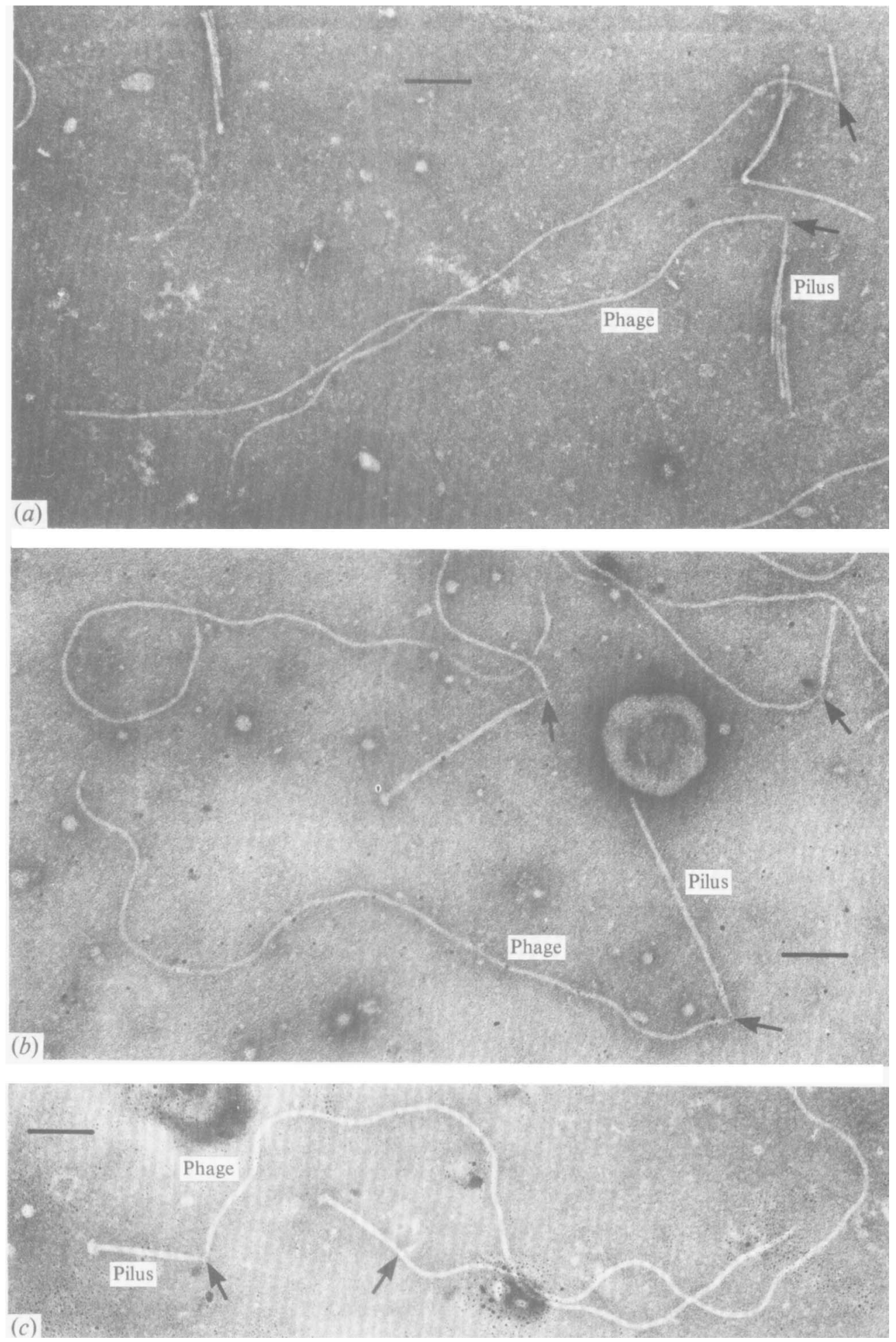

Fig. 1. Phage $X$ virions adsorbed to the tips of conjugative pili detached from cells. Arrows mark points of attachment. (a) X pili: they more closely resemble rigid rather than thick flexible pili, because they are unusually short when prepared from $6 \mathrm{~h}$ plate cultures (Bradley, unpublished). (b) N pili. (c) P-10 pili. The bar markers represent $100 \mathrm{~nm}$. 
Phage morphology. Under standard negative-staining conditions, phage $\mathrm{X}$ appeared as a curly filament (Fig. $1 b, c$ ) approximately $9 \mathrm{~nm}$ thick. The measurement of 81 virions gave a modal length of $1155 \mathrm{~nm}$ and a mean length of $1177 \pm 80 \mathrm{~nm}$. Occasionally, particles approximately double this length were encountered but these were not included in the calculation of the mean length.

Adsorption site. The adsorption of bacteriophages to pilus tips can best be visualized by examining mixtures of phage and free pili (Bradley, 1978b). Phage X attached to the tips of $\mathrm{X}$ pili (Fig. $1 a$ ), N pili (Fig. $1 b$ ) and P-10 pili (Fig. 1c), but no adsorption could be detected with W pili (not shown, and see below). The distal ends (tips) of conjugative pili are usually identifiable as being pointed and the proximal ends often have basal knobs (Bradley, 1980 a, $b$ ). These were not entirely obvious with the X pili (Fig. $1 a$ ). Indications of the efficiencies of attachment were obtained by counting random phage $\mathrm{X}$ virions with and without attached pili in the electron microscope. For samples of 100 virion, 58 virions were attached to $\mathrm{X}$ pili, 48 to $\mathrm{N}$ pili, 38 to $\mathrm{P}-10$ pili, and none to $\mathrm{W}$ pili. An extended search beyond the 100 virion sample revealed no adsorption to $\mathrm{W}$ pili. Bearing in mind that pilus concentrations could not be estimated, it seems that the first three kinds of pilus were about equally efficient at adsorbing phage $X$. With only one exception, single virions were attached to pili, not pairs as has been observed for some filamentous phages (see Bradley, 1977, 1978b). Other pilus types were not tested for phage $\mathrm{X}$ adsorption.

Ribonuclease sensitivity. The titre of phage $\mathrm{X}$ on RNAase-containing plates was the same as on control plates which lacked RNAase. The activity of phage $\mathrm{C}-1$, used as a positive control, was totally inhibited by the same concentration of RNAase.

Organic solvent sensitivity. The phage was stable in the presence of diethyl ether but its activity was totally inhibited by treatment with chloroform.

Serological comparison with phage IKe. Because the filamentous phages $\mathrm{X}$ and IKe had overlapping host ranges (see below) and were approximately the same length, they were tested for serological relatedness using immune electron microscopy. Anti-IKe serum gave a strong reaction with phage $\mathrm{IKe}$ but no reaction with phage $\mathrm{X}$ (not shown). The phages are thus serologically unrelated.

Host range. The phage plated on E. coli, S. typhimurium and Ser. marcescens strains carrying plasmid R6K but failed to form plaques on strains of $P$. mirabilis, $P$. morganii or $P r$. alcalifaciens harbouring this plasmid, although the phage multiplication test was positive (Table 1). No phage increase was observed in bacteria of any of the above species lacking transmissible R plasmids. The transfer frequencies of R6K from the Proteus and Providence strains to strain J62-1 were about $1 \times 10^{-4}$ per donor, whereas the plasmid transferred from strain J53 to J62-1 at a frequency more than 1000-fold higher (not shown). Phage X registered a positive phage multiplication test on $\mathrm{J} 53$ carrying plasmid $\mathrm{R} 485$ or other IncX plasmids repressed for pilus synthesis (Bradley, $1980 \mathrm{~b}$ ) but failed to multiply on J53(R711b) (Table 1).

The phage also plated on strain LT2trpA8 carrying the group M plasmid Rip69 and produced increases in titre on strains of J53 harbouring other IncM plasmids (Table 1). Plasmid Rip69 transferred from the $S$. typhimurium strain to strain J53-1 at a frequency of 5 $\times 10^{-2}$ per donor cell, whereas R446b transferred from strain J53 to J62-1 at a 1000 -fold lower frequency (not shown).

Phage X plated on hosts carrying each of the group $\mathrm{N}$ plasmids tested. These plasmids are all constitutive for pilus synthesis (Bradley, $1980 \mathrm{~b}$ ).

The phage also plated on $E$. coli strains carrying group P-1 plasmids RP4, R751 or R772 (Table 1). These plasmids are constitutive for pilus synthesis (Coetzee et al., 1979). The adsorption of phage X to pili of the group P-10 plasmid R91.5 was demonstrated (Fig. 1c) but no multiplication occurred on Ps. aeruginosa PAO1150.1(R91.5) in spite of the fact that the plasmid is constitutive (Jacoby et al., 1978). Likewise, no multiplication could be detected on other Ps. aeruginosa strains carrying representative plasmids of Pseudomonas incompatibility groups P-2, P-3, P-5, P-7, P-8, P-9 or P-11 (Table 1). 
Table 1. Host range of phage $X$

Drops of phage suspension (titre $1 \times 10^{9}$ plaque-forming units $\mathrm{ml}^{-1}$ ) were spotted on lawns of organisms contained in top-layer agar. Phage multiplication was determined as described in Methods.

Phage action

Host

LT2trpA8(R724)

LT2 trpA8(P-lac)

LT2trpA8(pHH1184)

J53-1(R711b)

J53-1(R840)

J53(R1drd19)

LT2trpA8(EDP208)

LT2trpA 8(R478)

J53(R64drd11)

J53(TP114)

LT2trpA8(R997)

LT2trpA8(Rip69)

J53(R446b)

J53(Rip 135)

J53(R471-1)

LT2 $\operatorname{trpA8}$ (R447b)

J53(N3)

J53(R390)

J53(R 199)

J53(R46)

J53(R 15)

J62-1(RP4)

J62-1(R772)

J53-1(R751)

PAO1150.1(R91.5)

J53(R402)

J53(Rts1)

LT2 $\operatorname{trp} A 8$ (RA3)

J53(R1460)

LT2 $\operatorname{trpA8}$ (R 769)

LT 2 trpA 8 (RSa)

J53(R 1230)

J53(R 1222)

J53(R6K) ॥

LT2 $\operatorname{trp} A 8$ (R6K)

SM89(R6K)

PM5006(R6K)

2815 nal-r(R6K)

P29nal-r(R6K)

J53(R485)

J53(pHH1187)

J53(TP231)

J53(TP227)

J53(TP228)

J53(PVS115)

J53(PVS 1 12)

J53(R775)

\section{Plasmid \\ Inc group}

B
C
C
D

D

FII

$F_{\mathrm{o}}$ lac

$\mathrm{H} 2$

I $\alpha$

I2

J

M

M

M

N

N

N

N

N

P-1

P-1

P. 1

P. 10 \$

$\mathrm{T}$

$\mathrm{T}$

U

U

V

W

W

$\mathrm{X}$

$\mathrm{X}$

$\mathrm{X}$

$\mathrm{X}$

$\mathrm{X}$

$\mathrm{X}$

$\mathrm{X}$

$\mathrm{X}$

$\mathrm{X}$

X

X

$\overbrace{\begin{array}{c}\text { Plaque } \\ \text { formation* }\end{array} \quad \text { Multiplication } \dagger}^{\text {Pot }}$

$\begin{array}{ll}- & \text { Sirg } \\ - & \text { Sirg } \\ - & \text { Sirg } \\ - & \text { Bra }\end{array}$

Sirgel et al. (1981)

Sirgel et al. (1981)

Sirgel et al. (1981)

Bradley (1977);

D. E. Bradley (unpublished)

D. E. Bradley (unpublished)

Jacob et al. (1977)

Armstrong et al. (1980)

Bradley (1980a)

Datta et al. (1971)

Grindley et al. (1973)

Bradley $(1980 a)$

Coetzee (1979)

Jacob et al. (1977)

Jacob et al. (1977)

Richards \& Datta (1979)

Jacob et al. (1977)

Hedges (1972)

Jacob et al. (1977)

Jacob et al. (1977)

Jacob et al. (1977)

Jacob et al. (1977)

Coetzee et al. (1979)

Coetzee et al. (1979)

Coetzee et al. (1979)

Jacoby et al. (1978)

Coetzee et al. (1972)

Jacob et al. (1977)

R. W. Hedges (unpublished)

R. W. Hedges (unpublished)

Hedges (1975)

Coetzee et al. (1979)

Hedges (1980)

Hedges (1980)

Bradley $(1980 b)$

Sirgel et al. (1981)

This investigation

This investigation

This investigation

This investigation

Bradley (1978a)

See Bradley $(1980 b)$

See Bradley $(1980 b$ )

See Bradley (1980 $b$ )

See Bradley (1980b)

Caudry \& Stanisich (1979)

Caudry \& Stanisich (1979)

See Bradley $(1980 b)$

* + , Plaques observed; - , no plaques observed.

$\dagger+$, At least a 10 -fold phage titre increase above that of the negative control obtained on three separate occasions; - , no increase in phage titre above that of the negative control; ND, not done.

$\ddagger$ Plasmid EDP208 is a derepressed version of $\mathrm{F}_{\mathrm{o}}$ lac isolated by N. Willetts (see Armstrong et al., 1980) and has a unique compatibility specificity (Datta, 1979).

$\S$ Phage $\mathrm{X}$ adsorption to $\mathrm{P}-10$ pili was demonstrated electron microscopically (Fig. $1 \mathrm{c}$ ). No phage multiplication could be demonstrated on strain PU21 carrying plasmids belonging to incompatibility groups P-2, P-3, P-5, P-7, P-8, P-9 or P-11 (not shown).

II Plasmids R6K and R6Kdrd (=Tem drd. see Bradley, 1980 b) are derepressed to the same degree for pilus synthesis (Bradley, unpublished).

T Plasmid R775 has a unique compatibility specificity and specifies pili corresponding to those of morphological group 3 (Bradley, 1980 b). 
The non-repressible plasmid RA3, which was originally classified as IncW (Hedges \& Datta, 1971), and which has now been reassigned to a new incompatibility group tentatively designated U (R. W. Hedges, unpublished) conferred phage X sensitivity on its host strain. However, R 1460 (also group U) only permitted a titre increase in strain J53 (Table 1).

Phage $\mathrm{X}$ increased in titre on strains bearing plasmids of the $\mathrm{W}$ incompatibility group but plaques were not observed, while plasmid R775 (a single plasmid possessing a unique specificity) allowed the phage to plate on its host (Table 1). None of the plasmids belonging to other incompatibility groups conferred phage $\mathrm{X}$ sensitivity on their hosts (Table 1).

\section{DISCUSSION}

For reasons that are not completely understood (see below), plasmid-specific phages do not necessarily plaque on species of all bacterial genera harbouring a plasmid which confers sensitivity (see Bradley, 1977; Coetzee et al., 1979; Sirgel et al., 1981). Hua et al. (1981) demonstrated that a strain of Caulobacter vibrioides modified RP1-specified pili to the extent that the latter did not adsorb phage PRR1 while still retaining their conjugal function. However, the readiest explanation for the failure of Proteus and Providence strains carrying $\mathrm{R} 6 \mathrm{~K}$ to plaque phage $\mathrm{X}$ is that pilus synthesis is poorly expressed in those organisms (see Results).

Phage X generally obeyed the rule of forming plaques on bacteria carrying a particular plasmid constitutive for sensitive pilus synthesis, while only registering an increase in titre on hosts harbouring depressed varieties of similar plasmids. This is illustrated by results obtained with $\mathrm{R} 6 \mathrm{~K}$ and the group X plasmids repressed for pilus synthesis in $E$. coli as well as those obtained with plasmids belonging to the $\mathrm{N}, \mathrm{P}-1$ and $\mathrm{U}$ incompatibility groups (Table 1). On this basis (and see Results), plaque formation on LT2trpA8(Rip69) indicated that the latter plasmid was non-repressible in the particular background strain (see Coetzee, 1979). The same argument could apply to R775 which is listed as depressed for pilus synthesis (Bradley, $1980 b$ ). Two anomalies were encountered. Firstly, although P-10 pili (R91.5: Fig. 1c, Table 1) were efficient receptors, no phage $X$ multiplication occurred with a Ps. aeruginosa strain carrying R91.5. An explanation could be that certain phage X genes are poorly expressed in this host. Secondly, group W plasmids, all of which are constitutive for pilus synthesis (Bradley, $1980 \mathrm{~b}$ ), only conferred limited sensitivity to phage X (titre increase, not plaque formation). Here, the observed explanation was very poor adsorption to $\mathrm{W}$ pili (see Results). It is concluded that, for phage $X$, plaque formation indicates that a resident plasmid is constitutive for pilus synthesis but that a phage titre increase without plaque formation, on a particular host, does not necessarily imply depression.

Results obtained with the M, P-10 and U group plasmids, as well as the single plasmid R775, have now brought these plasmids into the ambit of a phage susceptibility group-pattern, while reactions of the phage with strains carrying $\mathrm{R} 485$ or $\mathrm{R} 711 \mathrm{~b}$ have confirmed the present arrangement of the $\mathrm{X}$ incompatibility group and the determination of $\mathrm{X}$ pili by R485 (see Introduction).

The filamentous phage IKe (Khatoon et al., 1972) also propagates on hosts carrying group N (Dennison \& Baumberg, 1975) or P-1 plasmids (Grant et al., 1978). The phages are of similar length but phage $\mathrm{X}$ has a curly appearance and does not adsorb anti-IKe antibodies. It is therefore unlikely that they are closely related.

The most significant characteristic of phage $\mathrm{X}$ is its broad host range. Phages adsorbing to pilus tips are known (see Coetzee et al., 1979, 1980) to adsorb to serologically different pili coded for by limited ranges of plasmids from different incompatibility groups. Bradley \& Meynell (1978) suggested that the non-specificity of the adsorption mechanism of F-specific filamentous phages explained the attachment of these phages to tips of pili coded for by plasmids of both the $\mathrm{F}$ complex and $\mathrm{F}_{\mathrm{o}}$ lac. This is, however, the first report of a phage-host spectrum transgressing pilus morphological group boundaries: $\mathrm{X}$ pili are thick and flexible 
(see Introduction) whereas pili of all other plasmids conferring phage $\mathrm{X}$ sensitivity are rigid and belong to pilus morphological group 3 (Bradley, $1980 a, b$ ).

D. E. Bradley acknowledges the support of the Medical Research Council of Canada (Grant No. MA5608).

\section{REFERENCES}

Armstrong, G. D., Frost, L. S., Sastry, P. A. \& PARANCHYCH, W. (1980). Comparative biochemical studies on F and EDP208 conjugative pili. Ionmal of Bacteriology 141, 333-341.

BradLEY, D. E. (1977). Characterization of pili determined by drug resistance plasmids $\mathrm{R} 7 \mathrm{ll} \mathrm{b}$ and R778b. Journal of General Microbiolog! 102. 349-363.

Bradley, D. E. (1978a). Determination of very thin pili by the bacterial drug resistance plasmid R 485 . Plasmid 1, 376-387.

Bradley, D. E. $(1978 b)$. Determination of pili by bacterial drug resistance plasmids assigned to the $\mathrm{X}$ incompatibility group. In Pili, pp. 355-371. Edited by D. E. Bradley. E. Raizen. P. Fives Taylor \& J. Ou. Washington. D.C.: International Conterences on Pili.

Bradley, D. E. $(1980 a)$. Determination of pili by conjugative bacterial drug resistance plasinids of incompatibility groups B, C, H, J, K, M, V and X. Journal of Bacteriology 141, 828-837.

BradLEy, D. E. $(1980 b)$. Morphological and serological relationships of conjugative pili. Plasmid 4 . $155-169$.

Bradley, D. E. \& MEYNell, E. (1978). Serological characteristics of pili determined by the plasmids $\mathrm{R} 71 \mathrm{lb}$ and $\mathrm{F}_{\mathrm{o}}$ lac. Journal of General Microbiology 108, 141-149.

Caudry, S. D. \& Stanisich, V. A. (1979). Incidence of antibiotic-resistant Escherichia coli associated with frozen chicken carcasses and characterization of conjugative $\mathrm{R}$ plasmids derived from such strains. Antimicrobial Agents and Chemotherap! 16. 70!-709.

Coetzee, J. N. (1979). Patterns of mobilization of the Proteus mirabilis chromosome by $\mathrm{R}$ plasmids. Journal of General Microbiology 111, 243-251.

Coetzee, J. N., Datta, N. \& Hedges, R. W. (1972). $\mathrm{R}$ factors from Proteus rettgeri. Journal of (ieneral Microbiology 72, 543-552.

Coetzee, J. N., Lecatsas, G., Coetzee, W. F. \& Hedges, R. W. (1979). Properties of R plasmid R772 and the corresponding pilus-specific phage PR772. Journal of General Microbiologl 110. 263-273.

Coetzee, J. N., Sirgel. F. A. \& Lecatsas. G. ( 1980$)$. Properties of a filamentous phage which adsorbs to pili coded by plasmids of the Incl complex. Joumal of General Microbiology 1 17, 547-551.

DATTA, N. (1977). Classification of plasmids as an aid to understanding their epidemiology and evolution. Journal of Antimicrobial Chemotherapy 3, iSuppl. C), 19-23.

DAtTA, N. (1979). Plasmid classification: incompatibility grouping. In Plasmids of Medical, Environmental and Commercial Importanice. pp. 3-12. Edited by K. N. Timmis \& A. Pühler. Amsterdam: Elsevier/North-Holland.
Datta, N., Hedges, R. W., Shaw, E. J., Sykes, R. P. \& Richmond. M. H. (1971). Properties of an R factor from Pseudomonas aeruginosa. Journal of Bacteriology 108, 1244-1249.

Dennison. S. \& Baumberg, S. (1975). Unusual characteristics of the receptor for the $\mathrm{N} \operatorname{sex}$ factor-specific filamentous phage IKe. Genetical Research 25, 275-284.

Grant, R. B., Whiteley, M. H. \& Shapley, A. J. (1978). Plasmids of incompatibility group $P$ code for the capacity to propagate bacteriophage IKe. Journal of Bacteriology 136, 808-811.

Grindley, N. D. F.. Humphreys, G. O. \& ANDERSON, E. S. (1973). Molecular studies of R factor compatibility groups. Journal of Bacteriology 115, 387-398.

HedGes, R. W. (1972). Phenotypic characterization of $\mathrm{fi}^{-} \mathrm{R}$ factors determining the restriction and modification of $h s p$ II specificity. Molecular and General Genetics 115, 225-233.

Hedges, R. W. (1974). R factors from Providence. Journal of General Microbiology 81, 171-181.

Hedges, R. W. (1975). R factors from Proteus mirabilis and P. vulgaris. Journal of General Microbiology 87, 301-311.

Hedges, R. W. (1980). R factors of Serratia. In The Genus Serratia, pp. 139-153. Edited by A. von Graevenitz \& S. J. Rubin. Boca Raton, Florida: C.R.C. Press.

Hedges, R. W. \& Datta, N. (1971). Fi- R factors giving chloramphenicol resistance. Nature, London 234, 220-221.

Hedges, R. W., Datta, N., Coetzee, J. N. \& DENNISON, S. (1973). R factors from Proteus morganii. Journal of General Microbiology $\mathbf{7 7}$, 249-259.

Hua, T.-C., Scholl, D. R. \& Jollick, J. D. (1981). Functional modification of the plasmid RP1specified pilus by Caulobacter vibrioides. Journal of General Microbiology' 124, 119-128.

JaCob, A. E., Shapiro, J. A., Yamamoto, L., Smith, D. I., Cohen, S. N. \& Berg, D. (1977). Plasmids studied in Escherichia coli and other enteric bacteria. In DNA Insertion Elements, Plasmids and Episomes, pp. 607-638. Edited by A. I. Bukhari, J. A. Shapiro \& S. L. Adhya. New York: Cold Spring Harbor Laboratory.

JaCoby, G. A., Weiss, R., Korfhagen, T. R., Krishnapillai, V., Jacob. A. E. \& Hedges, R. W. (1978). An explanation for the apparent host specificity of Pseudomonas plasmid R91 expression. Journal of Bacteriology 136, 1159-1164.

Khatoon, H., IYER, R. V. \& IYER, V. N. (1972). A new filamentous bacteriophage with sex-factor specificity. Virology 48, 145-155.

Kontomichalou, P.. Mitani, M. \& Clowes, R. C. (1970). Circular R-factor molecules controlling penicillinase synthesis, replicating in Escherichia coli 
under either relaxed or stringent control. Journal of Bacteriology 104, 34-44.

LAWN, A. M. (1967). Simple immunological labelling method for electron microscopy and its application to the study of filamentous appendages of bacteria. Nature, London 214, 1151-1152.

MCConnell, M. M., Willshaw, G. A., Smith, H. R., Scotland, S. M. \& Rowe, B. (1979). Transposition of ampicillin resistance to an enterotoxin plasmid in Escherichia coli strain of human origin. Journal of Bacteriology 139, 346-355.

Meynell, G. G. \& LAwn, A. M. (1968). Filamentous phage specific for the I sex factor. Nature, London 217, 1184-1186.

Richards, H. \& DatTa, N. (1979). Reclassification of incompatibility group L (IncL) plasmids. Plasmid 2, 293-295.
Richards, H. \& Nugent, M. (1979). The incidence and spread of transposon 7. In Plasmids of Medical, Environmental and Commercial Importance, pp. 195-198. Edited by K. N. Timmis \& A. Pühler. Amsterdam: Elsevier/North Holland.

Sirgel, F. A., Coetzee, J. N., Hedges, R. W. \& Lecatsas, G. (1981). Phage C-1: an IncC group plasmid-specific phage. Journal of General Microbiology 122, 155-160.

Watanabe, M. \& August, J. T. (1967). Methods for selecting RNA bacteriophage. Methods in Virology 3, 337-350.

Yamamoto, K. R., Alberts, B. M., Benzinger, R., LAWHORNE, L. \& TREIBER, G. (1970). Rapid bacteriophage sedimentation in the presence of polyethylene glycol and its application to large-scale virus purification. Virology 40, 734-744. 